\title{
Humic Substances and Mineral Elements Contents of White Grubs and Waste Deposit
}

\author{
*A. J. Alhassan and M. S. Sule \\ Department of Biochemistry, Bayero University, Kano \\ [Corresponding Author ajalhassan@yahoo.com]
}

\begin{abstract}
The humic substances and mineral elements content of white grubs (WG) and waste deposit (WD) were analyzed. WG was found to contain higher amount of fulvic acid $(16.05 \pm 4.28 \%)$ and humic acid $(9.50 \pm 2.06 \%)$ compared to the respective value of $2.75 \pm 0.38 \%$ and $4.25 \pm 1.05 \%$. It could be inferred that WG accumulate these humic substances (humic and fulvic acids) from the environmental waste and these probably contribute to medicinal properties of the grubs. The mineral elements $\mathrm{Fe}, \mathrm{Mn}$, $\mathrm{Na}, \mathrm{K}, \mathrm{Ca}$, and Co were significantly $(\mathrm{p}<0.05)$ higher in WG compared to the WD, also indicating possible accumulation by the WG. In general the mineral contents of white grub in terms of relative concentration was found to be in rank of $\mathrm{K}>\mathrm{Mg}>\mathrm{Na}>\mathrm{Ca}>\mathrm{Mn}>\mathrm{Zn}>\mathrm{Fe}>\mathrm{Cu}$. These elements were found in appreciable amount to meet nutritional requirements. WG could, therefore, be nutritionally and medically relevant.
\end{abstract}

Key Words: White grubs, humic substances, Mineral elements, and waste deposit

\section{INTRODUCTION}

White grub (WG) is a larval stage of beetle metamorphosis and beetle is of various species. Dung beetles play a crucial role by burying dung in natural savannah and grassland used for cattle grazing in Africa (Brussard and Hijdrin, 1986). In addition to their effect on plants, other species biodegrade environmental wastes. A functional group found in soil consists of a group of organisms that have the same function and similar impact on soil and are called macro fauna and white grub is one of them (Gitay and Nobel, 1997). They are distinguished into micro $\ddot{i}$ predators, liter transformers and ecosystem engineers (Lavelli, 1997). They collectively stimulate mineralization of soil organic matter (Ingham et al., 1985; Couteaux et al., 1991), decompose and transform litle (Swift et al., 1979; Lavelli, 1996) and produce physical structures through which they can modify the availability or accessibility of resource for other organisms (Jones et al., 1994); thereby producing ñoiogenicò structures (Anderson, 1995). The functional role of these structures is thought to be important because they represent sites where certain ecological processes occur: stimulation of microbial activity; formation of soil structure; soil organic matter (SOM) dynamics, and exchange of water and gas (Lavelli, 1997). Another biological effect of soil macro fauna is the disappearance of dead animal materials and coprophgous organisms (feeding on dung or excrement) such as Diptera larvae, Coleoptera and Lapidoptera larvae and adult.

Humic compounds occurring in the soil and peat deposits play a vital role in the terrestrial and aquatic ecosystems (Frimmel and Christman, 1988). Farmers use humates to accelerate seed germination and improve rhizome growth (Elek, 1999). These materials are able to stimulate oxygen transport, accelerate respiration and promote efficient utilisation of nutrient by plants (Visser, 1987; Österberg and Mortensen, 1994; Elek, 1999). Livestock feed fortified with humic compounds result in improvements in the animals' reproduction cycles, resistance to diseases and growth rate (Aiken et al., 1985). These observations prompted scientists to study the specific properties of humates and their possible benefits in improving the health and well-being of humans. An important feature of humic substances is that they can combine with metal ions, oxides and clay minerals to form water soluble or insoluble complexes and can interact with organic compounds such as alkanes, fatty acids, capillary-active substances and pesticides (Aiken et al., 1985). Aiken et al. (1985) defined these substances as: ñA category of naturally occurring heterogeneous organic substances of 
high molecular weight that can be isolated from the environment and operationally defined in terms of their solubility." Humic substances evolve by the microbial degradation of plant and animal tissues and ultimately biomolecules (lipids, protein carbohydrates and lignin) dispersed in the environment after the death of living cells (Piccolo, 2002). Humic material is a supramolecular structure of relatively small bioorganic molecules (having molecular mass $<1000$ Da) self-assembled mainly by weak dispersive forces such as Van der Waals forces, '-', and $\mathrm{CH}$ ' bonds into only apparently large molecular sizes (Piccolo, 2002). It is well known that humic substances are the most stable fraction of organic matter in soils and can persist for tens, hundreds or even thousands of years (Piccolo, 2002). The dark color of humic substances is due partially to quinone structures formed at the environmental redox conditions and partially to enhance light absorption by the strictly associated chromophores (Piccolo, 2002). Humic compounds include; humus, a fraction of which is not soluble in water at any $\mathrm{pH}$ value; humic acid, a fraction which is not soluble in water under acid conditions (below pH 2) but becomes soluble at a greater $\mathrm{pH}$; fulvic acid a fraction of humic substances that is soluble under all $\mathrm{pH}$ conditions, and the phenolic acid which is a substance defined not on the basis of solubility but identified as a component of humic substances (Elek, 1999).

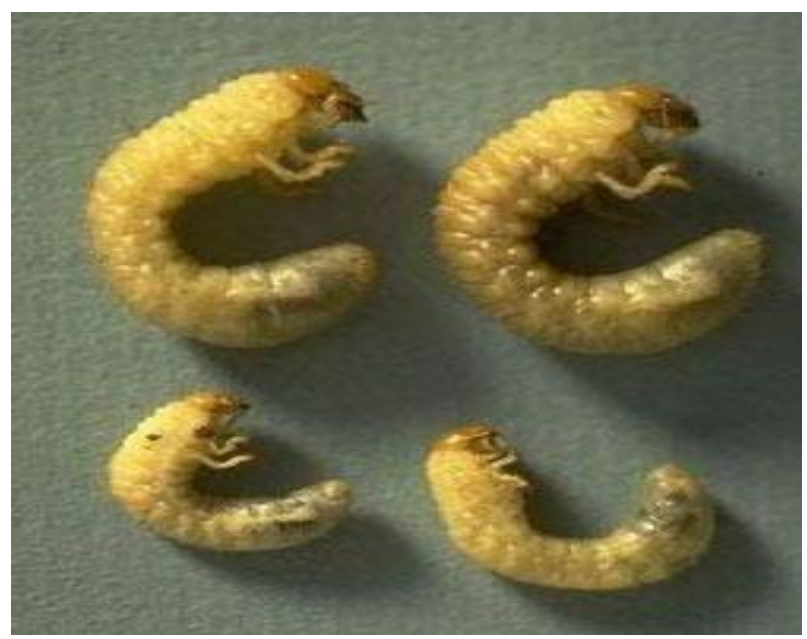

Figure 1: White grubs
The two most important groups of potentially therapeutic are humic and fulvic acids (Elek, 1999) and have chelating property, metabolic effects, scavenge free radicals, as antioxidants, due to their complex chemical structure. Just like humic acids, fulvic acids have been shown to be effective chelators of both mineral ions and heavy metals, as well as stimulators of oxidative phosphorylation and energy production (Elek, 1999). The research work reported in this paper was carried out to evaluate and compare the elemental and probable humic substance content of white grubsô(Figure 1) and its environmental waste.

\section{MATERIAL AND METHODS}

Sample Collection and Preparation: White grubs found in public wastes of Court Road, Tarauni Local Government, Kano State were collected at the same time, July and August, 2008, and waste deposit sample was also collected. Whole white grubs were cleaned of dirt and blot, and were oven dried for at least six hours at $110 €$, before being ground to powder and kept in plastic container at room temperature. The waste deposit was dried and ground to powder for humic substance and mineral element determination.

Analyses: Humic Substances from the White Grubs and Wastes samples were analysed as described by Thurman and Malcom (1981), Griffith and Schnitzer (1977) and Swift (1996). The elemental $(\mathrm{Pb}, \mathrm{Zn}, \mathrm{Fe}, \mathrm{Cr}, \mathrm{Na}, \mathrm{K}, \mathrm{Ca}, \mathrm{Co}, \mathrm{Mn}$ and $\mathrm{Mg}$ ) were determined as described by AMC, (1960); Cowley, 1980; John and Van (1980) and AOAC, (1999).

\section{RESULT AND DISCUSSION:}

Table 1 presents the percentage humic substances (fulvic acid, humic acid and humin) of dried white grubs and waste organic matter collected around Kano metropolis. White grub contains $16.05 \pm$ $4.28 \%$ fulvic acid, $9.50 \pm 2.06 \%$ humic acid and $74.65 \pm 11.31 \%$ humin, while the waste matter contains $2.75 .05 \pm 0.38 \%$ fulvic acid, $4.25 \pm 1.05$ $\%$ humic acid and $92.75 \pm 3.621 \%$ humin. Humin had the highest percentage, followed by humic acid and fulvic acid had the least in the dried waste matter analyzed. While in the white grubs analysed, humin also had the highest percentage, 
followed by fulvic acid and humic acid had the least percentage.

The levels of mineral elements from dried white grub and waste matter are presented in Table 2. Lead $(\mathrm{Pb})$ in waste deposit is higher than the level in white grubs. The mineral elements show the following distribution in white grubs $\mathrm{K}>\mathrm{Na}>\mathrm{Fe}$ $>\mathrm{Ca}$ and are all higher in white grub compared to waste matter. The levels of $\mathrm{Zn}, \mathrm{Cr}$, Co and $\mathrm{Mn}$ had similar distribution in both the white grubs and waste matter. $\mathrm{Cr}$ and $\mathrm{Mg}$ were found to be higher in waste than white grubs.

Table1: Humic substances in dried whole white grubs and from waste

\begin{tabular}{llc}
\hline Substance & $\begin{array}{l}\text { Waste } \\
\text { depot }(\%)\end{array}$ & $\begin{array}{l}\text { White grubs } \\
(\%)\end{array}$ \\
\hline Fulvic acid & $2.75 \pm 0.38$ & $16.05 \pm 4.28$ \\
Humic acid & $4.25 \pm 1.05$ & $9.50 \pm 2.06$ \\
Humin & $92.75 \pm 3.62$ & $74.65 \pm 11.31$
\end{tabular}

Values are expressed in mean and standard deviation (mean $\pm \mathrm{SD})$

Table 2: Concentration (mg/100g Samples) of mineral elements from white grubs and waste depot

\begin{tabular}{lll}
\hline Element & Waste depot & White grubs \\
\hline $\mathrm{Pb}$ & $18.00^{\mathrm{x}} \pm 2.24$ & $9.00^{\mathrm{x}} \pm 0.34$ \\
$\mathrm{Zn}$ & $1.00 \pm 0.02$ & $1.08 \pm 0.01$ \\
$\mathrm{Fe}$ & $13.00^{\mathrm{a}} \pm 3.21$ & $15.00^{\mathrm{a}} \pm 2.09$ \\
$\mathrm{Cu}$ & $9.00^{\mathrm{b}} \pm 0.83$ & $7.00^{\mathrm{b}} \pm 1.98$ \\
$\mathrm{Cr}$ & $0.90^{\mathrm{c}} \pm 0.06$ & $0.60^{\mathrm{c}} \pm 0.01$ \\
$\mathrm{Na}$ & $13.16^{\mathrm{y}} \pm 1.09$ & $15.80^{\mathrm{y}} \pm 3.12$ \\
$\mathrm{~K}$ & $12.90^{\mathrm{z}} \pm 1.20$ & $44.84^{\mathrm{z}} \pm 4.83$ \\
$\mathrm{Ca}$ & $2.00^{\mathrm{g}} \pm 0.31$ & $6.50^{\mathrm{g}} \pm 1.09$ \\
$\mathrm{Co}$ & $6.00 \pm 0.08$ & $6.50 \pm 0.12$ \\
$\mathrm{Mn}$ & $3.33 \pm 0.96$ & $3.67 \pm 0.08$ \\
$\mathrm{Mg}$ & $20.40^{\mathrm{r}} \pm 4.06$ & $11.70^{\mathrm{r}} \pm 2.19$ \\
\hline
\end{tabular}

From the result presented in Table1, white grub was found to contain higher amount of fulvic acid $(16.05 \pm 4.28 \%)$ and humic acid $(9.50 \pm 2.06 \%)$ compared to the waste matter $(2.75 \pm 0.38 \%$ and $4.25 \pm 1.05 \%$ fulvic acids and humic acids respectively). It could be inferred that white grubs accumulate these humic substances (fulvic and humic acids) from the environmental waste. They are produced due to microbial activities on plant and animal tissues and ultimately biomolecules (lipids, protein carbohydrates and lignin) dispersed in the environment after the death of living cells (Piccolo, 2002) and possibly by direct feeding on the waste. The acclaimed pharmacological roles of white grubs and/or its aqueous extract could be associated to the contents of the humic substances among others. Humic substances are shown to have effect on cell metabolism, enzymes, free radicals and minerals and they form complexes with amino acids, peptides, carbohydrates and steroids (Aiken et al., 1985; Elek, 1999). These physicochemical properties of humic substances may also be responsible for some of the effects occurring in tissues; including the elimination of heavy metals, desmutagenic effects, antioxidant and anticoagulant activity (Frimmel and Christman, 1988; Glynn, 1995; Lind and Glynn, 1999).

Humic substances were found to accelerate the rate of breakdown of glucose, leucine and uridine. However, they seem to retard the rate of incorporation of these organic molecules into the liver, but once they are absorbed, humic substances appear to accelerate their metabolism (Visser, 1973). Humic substance was found to increase the intestinal absorption of mineral elements (Glynn, 1995; Lind and Glynn, 1999). Users of white grub may benefit from these effects since it was found to contain appreciable level of these substances.

The possible explanation for frequent use of white grubs to manage general body weakness among Hausa $i ̈$ Fulani and other communities could be associated to the effects of humic substances in stimulating respiration and increasing the efficiency of oxidative phosphorylation in liver mitochondria (Visser, 1987). Liver and muscle use the ATP for energy to fuel various processes such as uptake of nutrients (Lehninger et al., 1993). As a result, more energy is generated for the individual for sustaining normal function and for compensating for extra energy requirement caused by illness or some other stress. Humic substances remove toxic metals likes cadmium, lead and mercury which are among the most toxic and ubiquitous environmental metallic contaminants to which the population is exposed 
(Shils and Shinke, 1994; Hudák et al., 1997). It has the ability to prevent the formation of genotoxic compounds that would affect the DNA of the cell (Aiken, et al., 1985) by adsorbing mutagens (Sato, 1987). They scavenge free radicals and thereby decrease blood-clotting activity, and has potential cardioprotective role (Klaöcking, 1991; Ferdinándy, 1997). Coronary blood flow, aortic blood flow and left ventricular and diastolic pressure were found to improve in the hearts of rats, subjected to ischaemic insult and treated with humic substances (Ferdinándy, 1997). Use of white grub may be encouraged by cardiovascular disease patients.

Lead $(\mathrm{Pb})$ concentration was found to be highest in waste deposit, but the value reduced to a half in white grubs (Table 2), which may be due to detoxification capacity of the grub (Shils and Shinke, 1994; Hudák et al., 1997). Lead has no known physiological role in the body; as such it accumulates and causes toxicity (Alhassan et al., 2009). The toxic effect of lead due to the use of white grubs for one reason or the other may not be possible because of the fact that it was found to be strongly bonded to humic substances found in the white grubs, hence making it less available in free form. The bioavailability of the humic substance was found to be $0.1 \%$ in a single administered dose to rats (Lind and Glynn, 1999). Zinc (Zn) concentration in white grubs was found to be comparable to that in the waste deposit (Table 2). This indicates possible equal distribution of the metal between them. Therefore users of white grubs may benefit from the biochemical roles of zinc. Zinc has an important biological role in enzyme systems. There are over 20 zinc containing enzymes (Lee, 1991; Halberge et al., 1993; Harrison and DeMora, 1996). The metal plays an important role in biological structure e.g. in beta cells of pancreas where it appears to stabilize insulin structures and in the retina, in position of choroids region of the eye.

The indicated higher level of $\mathrm{K}>\mathrm{Na}>\mathrm{Fe}>\mathrm{Ca}>$ $\mathrm{Mg}$ in this order compared to waste matter also shows possible bioaccumulation of these elements by the grubs and it may probably serve as nutritional and medicinal source of these metals. These metals have enormous physiological and biochemical functions. Iron is an important transition element with several vital functions in the body. It serves as a carrier of oxygen to the tissues from lungs (haemoglobin), storage of oxygen in the muscle (myoglobin), as a component of electron carrier in plant, animal and bacteria (cytochromes), e.t.c. It also serves as an integral part of important enzymes e.g. in aldehyde oxidase, catalase and peroxidase, in nitrogen fixing bacteria, e.t.c. (Lee, 1991). Copper is a metal cofactor for a variety of enzymes, including copper centers of cytochromes C oxidase, solid cytosolic peroxidase mutases, superoxide dismutase containing $\mathrm{Cu}$ and $\mathrm{Zn} . \mathrm{Na}$ is very rich in extracellular fluid. It regulates plasma volumes, acid-base balance, nerve and muscle function $\left(\mathrm{Na}^{+} / \mathrm{K}^{+}\right.$ATPase) (Robert et al., 2000). Sodium also plays a role in transportation of glucose (Na-Glucose Symporter). Potassium is an element as well as electrolyte, which is essential for the bodyôs growth and maintenance. It maintains normal water balance between the cell and body fluids. It plays role in nervous stimulation and muscle contraction. Calcium is stored in the bones and teeth where it functions to support these structures (Shils and Shinke, 1999). Calcium is needed for muscle contraction, blood vessel contraction and expansion, secretion of hormones and enzymes, blood coagulation e.t.c. (Food and Nutrition Board, 1997).

Waste matter had the highest concentrations of chromium $(\mathrm{Cr})$ and magnesium $(\mathrm{Mg})$ than the white grub. Even though it was not studied, probably the $\mathrm{Cr}$ in white grubs could be the non toxic form $\left(\mathrm{Cr}^{3+}\right)$, while that of the waste matter may be the total sum of the toxic and non toxic form. $\mathrm{Cr}$ is a mineral that humans require in trace amount. It is known to enhance the action of insulin (Halberge et al., 1993). Magnesium is the intracellular ion required for many enzymes activities particularly those involving ATP, forming ATP- $\mathrm{Mg}^{2+}$ complex, and for neuromuscular transmission. Magnesium is a constituent of bones, teeth, and cofactors of many enzymes. The concentrations of cobalt $(\mathrm{Co})$ and manganese $(\mathrm{Mn})$ in white grub and waste matter are relatively similar. Cobalt in small amount is essential to many living organism including humans. It is a central component of vitamin $\mathrm{B}_{12}$. 
$\mathrm{Mn}$ is an essential trace nutrient in all forms of life (Emsley, 2001). Some enzymes require $\mathrm{Mn}$ as a co-factor such as some oxidoreductases, hydrolases, isomerases, e.t.c. the reverse transcriptases of many retroviruses contain manganese. The medicinal and nutritional properties of white grubs could associated with mineral elements and humic substances its accumulate from the waste deposit.

\section{REFERENCES}

Aiken, G., McKnight, D. and Wershaw, R. (1985). Humic Substances in Soil, Sediment, and Water.Vol. 1.John Wiley, New York.

Alhassan, A.J., Sule, M.S., Hassan, J.A., Baba, B.A. and Aliyu, M.D. (2009). Proximate and elemental composition of white grubs. Bayero J. Pure Appl. Sci. 2(2): 188 ï 190.

AMC (1960). Analytical Methods Committee. Analyst. 84: 214.

Anderson, J.M. (1995). Soil organism as engineers: microsite modulation of macroscale progresses. In: Jones, C.G. and Lawton, J. H.(Eds.), Linking Species and ecosystems. Chapman and Hall, London. Pp. 94ї 106.

AOAC (1999). Methods of analysis, Association of Analytical Chemists. Washington DC

Brussard, L. and Hijdrin, R. D. W. (1986). Some effects of Scarab beetles in Sandy Soils of the Neitherlands. Geoderma 37(4): 325 ï 330.

Couteaux, M.,M., Mousseau, M., Celerier, M.L. and Bottner, P. (1991). Increased atmospheric $\mathrm{CO}_{2}$ litter quality: decomposition of sweet chestnut leaf litter with animal food webs of different complexities. Oikoss 61: 54 ï 64.

Cowley, K.M. (1980). Atomic Absorption Spectroscopy in Food Analysis Techniques. Applied Publisher ltd London. Pp 293 ï 319.

Elek, C. (1999). Humet Product Documentation and Technical Information. Horizon Multiplan LTD. Budapest. Pp 1-70.

Emsley, J. (2001). "Manganese". Nature's Building Blocks: An A-Z Guide tothe
Elements. Oxford University Press, Oxford. Pp. 249ї 253. ISBN 0198503407.

Ferdinándy, P. (1997). Cardioprotective effects of SHA and HA preparations in the Isolated working rat heart subjected to ischaemia/reperfusion, (unpublished).

Food and Nutrition Board (1997). Institute of Medicine. Standing Committee on the Scientific Evaluation of Dietary Intakes, Dietary Reference Intakes for Calcium, Phosphorus, Magnesium, Vitamin D and Fluoride. Washington DC: The National Academic Press.

Frimmel, F.H. and Christman, R.F. (1988). Humin Substances and Their Role in the Environment. $1^{\text {st }}$ ed. Vol.1., WileyInterscience Publication: New York. PP $60-123$.

Gitay, H. and Nobel, I.R. (1997). What are functional types and how should we seek them? In: Smith, T. M.., Shugart, H. H. and Woodward, F. I.(Eds.). Plant Functional Types. Their Relevance to ecosystem Properties and Global Change. Cambridge University Press, Cambridge. Pp. 3 -19.

Glynn, A.W. (1995). Fulvic and humic acids decrease the absorption of cadmium in the rat intestine. Archives of Toxicology,. 70: 28-33.

Griffith, S.M, and Schnitzer, M. (1977). Soil Science Amer. Proc. 39: 1131-11 38.

Halberge, L., Sandestrom B. and Aggett, P.J. (1993). Iron, Zinc and other trace elements. In: Garrow J. S., W. P. T. James and A. Ralph (eds.). Human Nutrition and Dietetics $\quad 9^{\text {th }} \quad$ edition. Churchill Livingstone, Edinburgh. Pp. 175 ï 207.

Harrison, R.H. and DeMora, S.J. (1996). Introductory Chemistry for Environmental Sciences. $2^{\text {nd }}$ ed. Cambrige University press. Pp $50-238$

Hudák, K. (1997). Effect of the consumption of humic acid with bound complex micro elements in cases of occupational cadmium exposure. Central Eur. J. Occup. Environ. Med. 3(3): 175-186.

Ingham, R.E., Trofymou, J.A. and Coleman, D.C. (1985). Interactions of bacteria, fungi and their nematode grazers: effects on nutrient 
cycling and plant growth. Ecol. Monogr., 55: 119 ï 140.

John, C. and Van, L. (1980). Atomic Absorption Spectrometer. In: Analytical Atomic Absorption Spectroscopy. Academic press, Inc. Orlando, Florida. Pp. 11 ï 293.

Jones, C. G., Lawton, J. H. and Shachack, M. (1994). Organisms as ecosystem engineers. Oikos 69: 373 ï 386.

Klöcking, H.P. (1991) Influence of natural humic acids and synthetic phenolic polymers on haemostasis. Arch. Toxicol. suppl 14: 166-169.

Lavelli, P. (1996). Diversity of soil fauna and ecosystem function. Biol. Int., 33: 117133.

Lavelli, P. (1997). Fauna activities and soil processes: adaptive strategies that determine ecosystem function. Adv. Ecol. Res. 27: 93 ï 132.

Lee, J.D. (1991). An introduction to transition element. In: Concise Inorganic Chemistry $4^{\text {th }}$ edition. Chapman and Hall, London. Pp. 654-881.

Lehninger, A., Nelson, D. and Cox, M. ( 1993). Principles of Biochemistry. $2^{\text {nd }}$ ed, Worth Publishers. New York:

Lind, Y. and. Glynn, A.W (1999). The influence of humic substances on the absorption and distribution of cadmium in mice. Pharmacol. Toxicol. 84: 267-273.

Österberg, R. and Mortensen, K. (1994). The growth of fractal humic acids: cluster correlation and gel formation. Radiat. Environ. Biophys 33: 269-276.

Piccolo, A. (2002). Supramolecular Structure of Humic Substances. Advances in Agronomy. A novel understanding of Humic. Chemistry and implications in soil science. 75:57 ï 134.

Robert, K. M., Daryl, K..G., Peter, A.M., Victor, W.R. (2000). Harperô Biochemistry, $25^{\text {th }}$ edition. Pp.360 Ï 721.

Sato, T. (1987) Mechanism of the desmutagenic effect of humic acid. Mutation Res. 176: 199-204.

Shils, O. and Shike, E.D. (1999). Modern Nutrition in Health and Disease, $8^{\text {th }}$ ed., Vol. 2. Williams and Wilkin, Baltimore. Pp 30 ï 65.

Swift, M.J., Heal, O.W. and Anderson, J.M. (1979). Decomposition. In: Terrestrial Ecosystems. Blackwell Scientific, Oxford. Pp. 32 ï 60.

Swift, R.S. (1996). Organic matter characterization. In: Methods of Soil Analysis. Part 3. Chemical methods. Soil Sci. Soc. Am. Book Series: 5. Soil Sci. Soc. Am., Madison, WI. Pp. 1018-102

Thurman, E.M. and Malcolm, R.L. (1981). Preparative isolation of aquatic humic substances. Environ. Sci. Technol. 15: 463-466.

Visser, S.A. (1987). Effect of humic substances on mitochondiral respiration and oxidative phosphorylation. The Sci. Total Environ. 62: 347-354. 